Technical paper

\title{
Benzimidazole or Diamide From a Reaction of Diamines and Carboxylic Acids or Acid Chlorides: Crystal Structures and Theoretical Studies
}

\author{
Felix Odame, ${ }^{1,{ }^{*}}$ Eric Hosten, ${ }^{1}$ Richard Betz, ${ }^{1}$ Kevin Lobb ${ }^{2}$ \\ and Zenixole R. Tshentu ${ }^{1}$ \\ ${ }^{1}$ Department of Chemistry, Nelson Mandela Metropolitan University, P.O. Box 77000, Port Elizabeth 6031, South Africa \\ ${ }^{2}$ Department of Chemistry, Rhodes University, P.O. Box 94, Grahamstown 6140, South Africa \\ * Corresponding author: E-mail: felixessah15@gmail.com \\ Tel: +2741504 2484; Fax: +27415041728
}

Received: 21-05-2015

\begin{abstract}
A reaction of an acid chloride with a diamine yielded a diamide. $m$-Toluic acid was chlorinated to $m$-toluoyl chloride and subsequently reacted with 4-methyl-o-phenylenediamine in pyridine to obtain 3-methyl- $N$-[2-(3-methylbenzamido)phenylbenzamide (I). 2-(3-Methylphenyl)-1H-benzimidazole (II) has been obtained upon reacting $o$-phenylenediamine with $m$-toluic acid in polyphosphoric acid and toluene. The compounds have been characterized by IR, NMR, microanalyses and GC-MS. The crystal structures of the compounds have been discussed. DFT calculations of the frontier orbitals of the precursor compounds have been carried out to ascertain the groups that contribute to the HOMO and LUMO, and to study their contribution to the reactivity in the formation of the diamides and benzimidazoles. The synthesis of the amide from a diamine was seen to be favoured in the presence of a good leaving group attached to the carbonyl as in the case of acid chloride. However, the synthesis of benzimidazoles was found to be favoured in the presence of an excess of a protonating agent and high temperature.
\end{abstract}

Keywords: $m$-toluic acid, diamine, diamide, benzimidazoles, crystal structures, frontier orbitals

\section{Introduction}

There are several reported means to access benzimidazoles; v.i.z. condensation of $o$-phenylenediamine with carboxylic acids in the presence of ring closing agents such as polyphosphoric acid and hydrochloric acid, ${ }^{1}$ zinc acetate catalysis at room temperature using $o$-phenylenediamine and aldehydes, ${ }^{2}$ and copper(I) catalyzed intramolecular arylation of formamidines to form 2-unsubstituted $\mathrm{N}$-substituted benzimidazoles. ${ }^{3}$ Cascade reactions of $o$-haloacetanilide derivatives with amidine hydrochlorides have also been catalyzed by copper(I) to yield benzimidazoles. ${ }^{4}$ Chiral benzimidazoles have also been synthesized from $o$-dibromobenzene by successive amination or imination followed by acid-catalyzed ring closure to give benzimidazoles with the substituted nitrogen atom bearing a chiral substituent. ${ }^{5}$

Acyl halides enable facile access to amides and they are prepared using chlorinating agents such as thionyl chloride, oxalyl chloride, phosphorus trichloride and phosphorus pentachloride. ${ }^{6,7}$ The acyl halide is not absolutely necessary: $\mathrm{ZnO}$ has been used as a catalyst in the formation of amides from formic acid and amines under solvent-free conditions at $70{ }^{\circ} \mathrm{C},{ }^{8}$ with excellent yield in short reaction times with reusability of catalyst. Extension to other catalysts have been reported, with catalytic amounts of indium trioxide being used in the conversion of carboxylic acid esters to primary amides, ${ }^{9}$ and Han et $a l,{ }^{10}$ have reported a process for preparation of amides from esters and amines using a catalytic system comprised of Group IV metal alkoxides in conjunction with additives including 1-hydroxy-7-azabenzotriazole (HOAt). In this case, the ester-amide exchange proceeds using a variety of structurally diverse esters and amines without azeotropic reflux to remove the alcohol by-product. Hydrogen peroxide has been used in the catalytic oxidative amidation between aldehydes and amines using $\mathrm{Pd}$ - 
$\mathrm{Cl}_{2}$-xantophos as a catalyst in methanol under acidic conditions. ${ }^{11} \mathrm{~N}$-Heterocylic carbene-based ruthenium complexes have been developed as highly active catalysts for direct amide synthesis from alcohols and amines. ${ }^{12} 12$ Tungstophosphoric acid supported on silica-coated magnetic nano-particles has also recently been used in the model synthesis of 1,2-disubstituted benzimidazole derivatives in water. ${ }^{13}$

The highest occupied molecular orbitals (HOMOs) and lowest unoccupied molecular orbitals (LUMOs) energy gaps have been evaluated by DFT. The frontier orbitals are useful in predicting the most reactive position in $\pi$ electron systems and also explain several types of reactions in conjugated systems. ${ }^{14}$ The conjugated molecules are characterised by a small highest occupied molecular orbital-lowest unoccupied molecular orbital gap (HOMO and LUMO separation), which is the result of a significant degree of intramolecular charge transfer from the end capping electron-donor groups through a $\pi$-conjugated path. ${ }^{15}$ The HOMO and LUMO are the main orbitals that determine chemical stability of any species. ${ }^{16}$ The HOMO represents the ability to donate an electron whilst the LUMO represents the ability to accept an electron. The energy of the HOMO is directly related to the ionization potential whilst the energy of the LUMO is related to the electron affinity. The energy difference between HOMO and LUMO orbitals, known as the energy gap, determines the stability or reactivity of molecules. ${ }^{17}$ The energy gap is a critical parameter in determining molecular electrical transport properties because it is a measure of electron conductivity. ${ }^{18}$ The hardness of a molecule also corresponds to the gap between the HOMO and LUMO orbitals. ${ }^{19}$

In an attempt to synthesize a 2-substituted benzimidazole by exploiting the ease of loss of the chloride, $m$-toluic acid was chlorinated to obtain $m$-toluolyl chloride which was then reacted with $o$-phenylenediamine in the presence of pyridine. This did not form benzimidazole but a diamide, with two moles of $m$-toluolyl chloride reacting with one mole equivalent $o$-phenylenediamine to form the diamide. It was however, also demonstrated that benzimidazole formation can be achieved by a reaction of $o$ phenylenediamine with the corresponding carboxylic acid (not the acyl halide) under acid-catalysed conditions (Figure 1). The crystal structures of I and II have been provided, and also discussed briefly, as conclusive evidence of the syntheses routes for diamides and benzimidazoles. DFT studies of the frontier orbitals (HOMO and LUMO) have been useful in studying the reactivity of the precursor compounds and in predicting the groups that contribute to these frontier orbitals. This helped in predicting the reactions that can happen at the sites that make up the frontier orbitals. The lack of reactivity of 2-(3-methylphenyl)- $1 H$-benzimidazole towards oxidation reactions has also been explained similarly and contrasted with compounds that undergo oxidation of their methyl groups.

\section{Experimental Methods}

\section{1. Reagent and Instrumentation}

Analytical grade reagents and solvents for synthesis and analysis which included $m$-toluic acid and $o$-phenylenediamine were obtained from Sigma Aldrich (USA) whilst pyridine, thionyl chloride, hexane, methanol, ethyl acetate and dimethyl sulfoxide were obtained from Merck Chemicals (SA). The chemicals were used as received (i.e. without further purification). ${ }^{1} \mathrm{H}$ NMR and ${ }^{13} \mathrm{C}$ NMR spectra were recorded on a Bruker Avance $\mathrm{AV} 400 \mathrm{MHz}$ spectrometer operating at $400 \mathrm{MHz}$ for ${ }^{1} \mathrm{H}$ and $100 \mathrm{MHz}$ for ${ }^{13} \mathrm{C}$ using DMSO- $d_{6}$ as solvent and tetramethylsilane as internal standard. Chemical shifts are expressed in ppm. FT-IR spectra were recorded on a Bruker platinum ATR spectrophotometer Tensor 27. Elemental analyses were performed using a Vario Elementar Microcube ELIII. Melting points were obtained using a Stuart Lasec SMP30 whilst the masses were determined using Agilent 7890A GC System connected to a 5975C VL-MSC with electron impact as the ionization mode and a triple-axis detector. The GC was fitted with a $30 \mathrm{~m}$ $\times 0.25 \mathrm{~mm} \times 0.25 \mu \mathrm{m}$ DB-5 capillary column. Helium was used as carrier gas at a flow rate of $1.63 \mathrm{~mL} / \mathrm{min}$ with an average velocity of $30.2 \mathrm{~cm} / \mathrm{s}$ and a pressure of $63.7 \mathrm{kPa}$.

\section{2. Preparative Work}

\section{3-Methyl- $N$-[2-(3-methylbenzamido)phenylbenzami- de (I)}

$m$-Toluic acid $(1.36 \mathrm{~g}, 0.01 \mathrm{~mol})$ was refluxed in thionyl chloride for $3 \mathrm{~h}$. The thionyl chloride was distilled off and the product ( $m$-toluolyl chloride) dried under vacuum for $16 \mathrm{~h}$. $o$-Phenylenediamine was reacted with $m$ toluolyl chloride under reflux in pyridine for $12 \mathrm{~h}$. The pyridine was distilled off and the crude product was dissolved in a small quantity of methanol and placed on a column. It was then eluted with hexane:ethyl acetate by gradient elution starting from $0 \%$ ethyl acetate up to $100 \%$. The elution was started with $50 \mathrm{~mL}$ of hexane $(100 \%)$, followed by $250 \mathrm{~mL}$ hexane:ethylacetate (1:20), and then $250 \mathrm{~mL}$ of hexane:ethylacetate $(1: 10)$, the column was further eluted with $250 \mathrm{~mL}$ of hexane:ethyl acetate (3:20) which gave the product. The elution was continued with $500 \mathrm{~mL}$ of hexane:ethyl acetate (1:5). and then with 250 $\mathrm{mL}$ of hexane:ethyl acetate (3:10) followed by $250 \mathrm{~mL}$ of hexane ethyl acetate $(1: 1)$, it was further eluted with 200 $\mathrm{mL}$ of ethyl acetate $(100 \%)$. The column was then washed with $250 \mathrm{~mL}$ methanol (100\%). Mp 148-150 ${ }^{\circ} \mathrm{C}$. Yield 32\%. ${ }^{1} \mathrm{H}$ NMR (ppm): 10.02 (s, N-H), 7.74 (m, 2H), 7.66 $(\mathrm{m}, 4 \mathrm{H}), 7.42(\mathrm{~m}, 4 \mathrm{H}), 7.30(\mathrm{~m}, 2 \mathrm{H}), 2.36(\mathrm{~s}, 6 \mathrm{H}) .{ }^{13} \mathrm{C}$ NMR (ppm): $20.9\left(\mathrm{CH}_{3}\right), 124.6(\mathrm{Ar}-\mathrm{H}), 125.6(\mathrm{Ar}-\mathrm{H})$, 125.7 ( $\mathrm{Ar}-\mathrm{H}), 128.0(\mathrm{Ar}-\mathrm{H}), 128.5(\mathrm{Ar}-\mathrm{H}), 131.3$ $(\mathrm{Ar}-\mathrm{H}), 132.4(\mathrm{Ar}-\mathrm{H}), 134.1(\mathrm{Ar}-\mathrm{H}), 137.9(\mathrm{Ar}-\mathrm{H})$, $165.8(\mathrm{C}=\mathrm{O})$. IR $\left(v_{\max }, \mathrm{cm}^{-1}\right): 3272(\mathrm{~N}-\mathrm{H}), 2916(\mathrm{C}-\mathrm{H})$, $1644(\mathrm{C}=\mathrm{O}), 1596(\mathrm{C}=\mathrm{C}), 1513(\mathrm{C}-\mathrm{N}), 1276(\mathrm{C}-\mathrm{O})$. Anal. Calcd for $\mathrm{C}_{22} \mathrm{H}_{20} \mathrm{~N}_{2} \mathrm{O}_{2}$ : C, 76.72; H, 5.85; N, 8.13. 
Found: C, 77.15; H, 6.30; N, 8.15. LRMS $\left(\mathrm{m} / \mathrm{z}, \mathrm{M}^{+}\right)$: Found for $\mathrm{C}_{22} \mathrm{H}_{20} \mathrm{~N}_{2} \mathrm{O}_{2} 344.41$, calcd mass 344.90 .

\section{2-(3-Methylphenyl)-1H-benzimidazole (II)}

$52 \mathrm{~g}$ of polyphosphoric acid, in $10 \mathrm{~mL}$ of toluene, was heated at $120^{\circ} \mathrm{C}$ for $30 \mathrm{~min}$. $m$-Toluic acid (13.6 g, 0.1 mol) and $o$-phenylenediamine $(0.1 \mathrm{~mol})$ were added and the mixture was heated at $165^{\circ} \mathrm{C}$ for $6 \mathrm{~h} .20 \mathrm{~mL}$ of water was added with stirring and then sodium hydrogen carbonate was added until effervescence ceased. The product was recrystallized from methanol:THF (1:1) and obtained as a white solid. Mp 213-215 ${ }^{\circ} \mathrm{C}$, Yield 89\%. ${ }^{1} \mathrm{H}$ NMR (ppm): 12.88 (s, 1H, N-H), 8.04 (d, 1H, Ar-H), 7.99 (d, 1H, Ar-H), 7.66 (m, 1H, Ar-H), 7.54 (s, 1H, Ar-H), 7.41 $(\mathrm{m}, 1 \mathrm{H}, \mathrm{Ar}-\mathrm{H}), 7.31(\mathrm{~m}, 1 \mathrm{H}, \mathrm{Ar}-\mathrm{H}), 7.20(\mathrm{~m}, 2 \mathrm{H}, \mathrm{Ar}-\mathrm{H})$, $2.41\left(\mathrm{~s}, 3 \mathrm{H}, \mathrm{CH}_{3}\right),{ }^{13} \mathrm{C} \mathrm{NMR}(\mathrm{ppm}): 151.5(\mathrm{C}=\mathrm{N}), 138.1$ $(\mathrm{Ar}-\mathrm{H}), 130.4(\mathrm{Ar}-\mathrm{H}), 130.2(\mathrm{Ar}-\mathrm{H}), 128.77(\mathrm{Ar}-\mathrm{H})$, 127.0 (Ar-H), 123.6 (Ar-H), $121.9(\mathrm{Ar}-\mathrm{H}), 115.0(\mathrm{Ar}-\mathrm{H})$, $21.0\left(\mathrm{CH}_{3}\right)$, IR $\left(v_{\max }, \mathrm{cm}^{-1}\right): 3052(\mathrm{~N}-\mathrm{H}), 2986(\mathrm{C}-\mathrm{H})$, $2879(\mathrm{C}-\mathrm{H}), 1661(\mathrm{C}=\mathrm{N}), 1590(\mathrm{C}=\mathrm{C}), 1487(\mathrm{C}-\mathrm{N})$. Anal. Calcd for $\mathrm{C}_{23} \mathrm{H}_{24} \mathrm{~N}_{2} \mathrm{O}_{3}$ : C, 74.97; $\mathrm{H}, 6.71 ; \mathrm{N}, 11.66$. Found: $\mathrm{C}$, 74.67; H, 6.42; N, 11.95. LRMS $\left(\mathrm{m} / \mathrm{z}, \mathrm{M}^{+}\right)$: found for $\mathrm{C}_{14} \mathrm{H}_{12} \mathrm{~N}_{2}$ 208.20, calcd mass 208.26.

\section{3. X-Ray Crystallography}

X-Ray diffraction analyses of I and II were performed at $200 \mathrm{~K}$ using a Bruker Kappa Apex II diffractometer with monochromated Mo K $\alpha$ radiation $(\lambda=0.71073 \AA)$. $\mathrm{APEXII}^{20}$ was used for data collection and SAINT, ${ }^{20}$ for cell refinement and data reduction. The structures were solved by direct methods using SHELXS-2013, ${ }^{21}$ and refined by least-squares procedures using SHELXL-2013, ${ }^{22}$ with SHELXLE, ${ }^{22}$ as a graphical interface. All non-hydrogen atoms were refined anisotropically. Carbon-bound $\mathrm{H}$ atoms were placed in calculated positions $(\mathrm{C}-\mathrm{H} 0.95 \AA$ for aromatic carbon atoms and $\mathrm{C}-\mathrm{H} 0.99 \AA$ for methylene groups) and were included in the refinement in the riding model approximation, with $U_{\text {iso }}(\mathrm{H})$ set to $1.2 U_{\text {eq }}(\mathrm{C})$. The $\mathrm{H}$ atoms of the methyl groups were allowed to rotate with a fixed angle around the $\mathrm{C}-\mathrm{C}$ bond to best fit the experimental electron density (HFIX 137 in the SHELX program suite, ${ }^{22}$ with $U_{\text {iso }}(\mathrm{H})$ set to $1.5 U_{\text {eq }}(\mathrm{C})$. Nitrogen-bound $\mathrm{H}$ atoms were located on a difference Fourier map and refined freely. Data were corrected for absorption effects using the numerical method implemented in SADABS. ${ }^{21}$

\section{4. Computational Studies}

The calculations were carried out using Gaussian 09 program. Molecular geometries of the singlet ground state of all the compounds were fully optimised in the gas phase at the density functional theory (DFT) level of theory using the hybrid B3LYP functional together with 6$31++\mathrm{G}$ basis set. For each compound a frequency calculation was carried out to ensure that the optimized molecular structure corresponded to a minimum, thus only positive frequencies were expected. The HOMO and LUMO results were viewed in Avogadro.

\section{Results and Discussion}

\section{1. Synthesis and Crystal Structures}

The synthesis of the diamides was readily achieved by the nucleophilic attack of the carbonyl by the diamine<smiles>Cc1cccc(C(=O)O)c1</smiles>

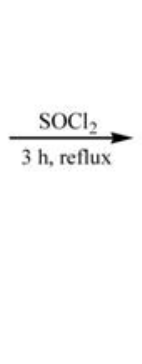<smiles>Cc1cccc(C(=O)Cl)c1</smiles>

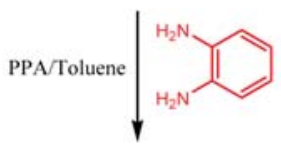

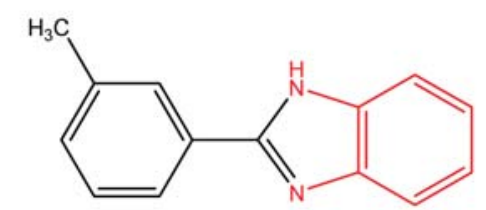

2-(3-Methylphenyl)-1 $H$-benzimidazole (II)

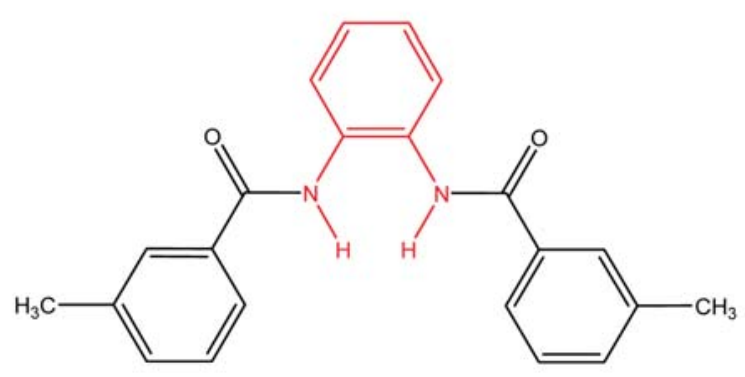

3-Methyl- $N$-[2-(3-methylbenzamido)phenylbenzamide (I)

Figure 1. A synthesis scheme of 3-methyl- $N$-[2-(3-methylbenzamido)phenylbenzamide (I) and 2-(3-methylphenyl)-1 $H$-benzimidazole (II). 
with the subsequent loss of a hydrogen chloride gas and this process is aided by the presence of a base such as pyridine to take up the protons from solution (Figure 1). The acid-catalysed synthesis of benzimidazole (Figure 1) proceeded by the protonation of the hydroxyl group and the subsequent attack of the carbonyl carbon by one of the amines with the loss of water from the carboxylic acid. The subsequent protonation of the carbonyl enables it to be attacked by the other amine group leading to the loss of water. This reaction is driven by high temperature and excess of protons. In the formation of the diamides the ease of loss of the chloride makes it easy for the amide to be formed but the absence of a proton source to protonate the carbonyl makes the second attack of the carbonyl by the other amine impossible. This resulted is the formation of an amide on the second amine of the diamines (diamide formation) rather than the cyclization to form a benzimidazole.

The FTIR spectra for compounds I and II are provided in Figures S1-S2 in the Supplementary Information. The ${ }^{1} \mathrm{H}$ NMR and ${ }^{13} \mathrm{C}$ NMR spectra for the compounds I and II are also provided in Figures S3-S6 in the Supplementary Information.

Compound I was recrystallized from ethyl acetate:hexane (1:3) and obtained as colourless crystals, whilst compound II was recrystalized from DMSO:
Table 1 Crystallographic data and structure refinement summary for compounds I and II

\begin{tabular}{ccc}
\hline Property & Compound I & Compound II \\
\hline Empirical formula & $\mathrm{C}_{22} \mathrm{H}_{20} \mathrm{~N}_{2} \mathrm{O}_{2}$ & $\mathrm{C}_{14} \mathrm{H}_{12} \mathrm{~N}_{2}$ \\
Formula weight & 344.40 & 208.26 \\
Temperature & 200 & 200 \\
Crystal system & trigonal & monoclinic \\
Space group & $R-3$ & $P 2_{1} / c$ \\
$a(\AA)$ & $28.7614(9)$ & $12.3990(6)$ \\
$b(\AA)$ & $28.7614(9)$ & $9.7826(5)$ \\
$c(\AA)$ & $11.7819(4)$ & $9.6028(4)$ \\
$\alpha\left({ }^{\circ}\right)$ & 90 & 90 \\
$\beta\left(^{\circ}\right)$ & 90 & $110.615(2)$ \\
$\gamma\left({ }^{\circ}\right)$ & 120 & 90 \\
Volume $\left(\AA^{3}\right)$ & $8440.5(7)$ & $1090.18(9)$ \\
$Z$ & 18 & 4 \\
$\mathrm{D}(\mathrm{Calc})\left(\mathrm{g} / \mathrm{cm}^{3}\right)$ & 1.220 & 1.269 \\
$F(000)$ & 3276 & 440 \\
Crystal size $\left(\mathrm{mm}^{3}\right)$ & $0.21 \times 0.28 \times 0.54$ & $0.08 \times 0.23 \times 0.56$ \\
$\mu(\mathrm{MoKa})\left(/ \mathrm{mm}^{3}\right)$ & 0.079 & 0.076 \\
Tot., Uniq. Data, $\mathrm{R}_{\text {int }}$ & $16186,4646,0.021$ & $12429,2692,0.014$ \\
{$[\mathrm{I}>2.0$ sigma $(\mathrm{I})]$} & 2944 & 2217 \\
$N$ ref & 4646 & 2692 \\
$N$ par & 302 & 150 \\
$R$ & 0.0511 & 0.0392 \\
$\mathrm{R}_{2}$ & 0.1554 & 0.1115 \\
$S$ & 1.02 & 1.03 \\
\hline & &
\end{tabular}

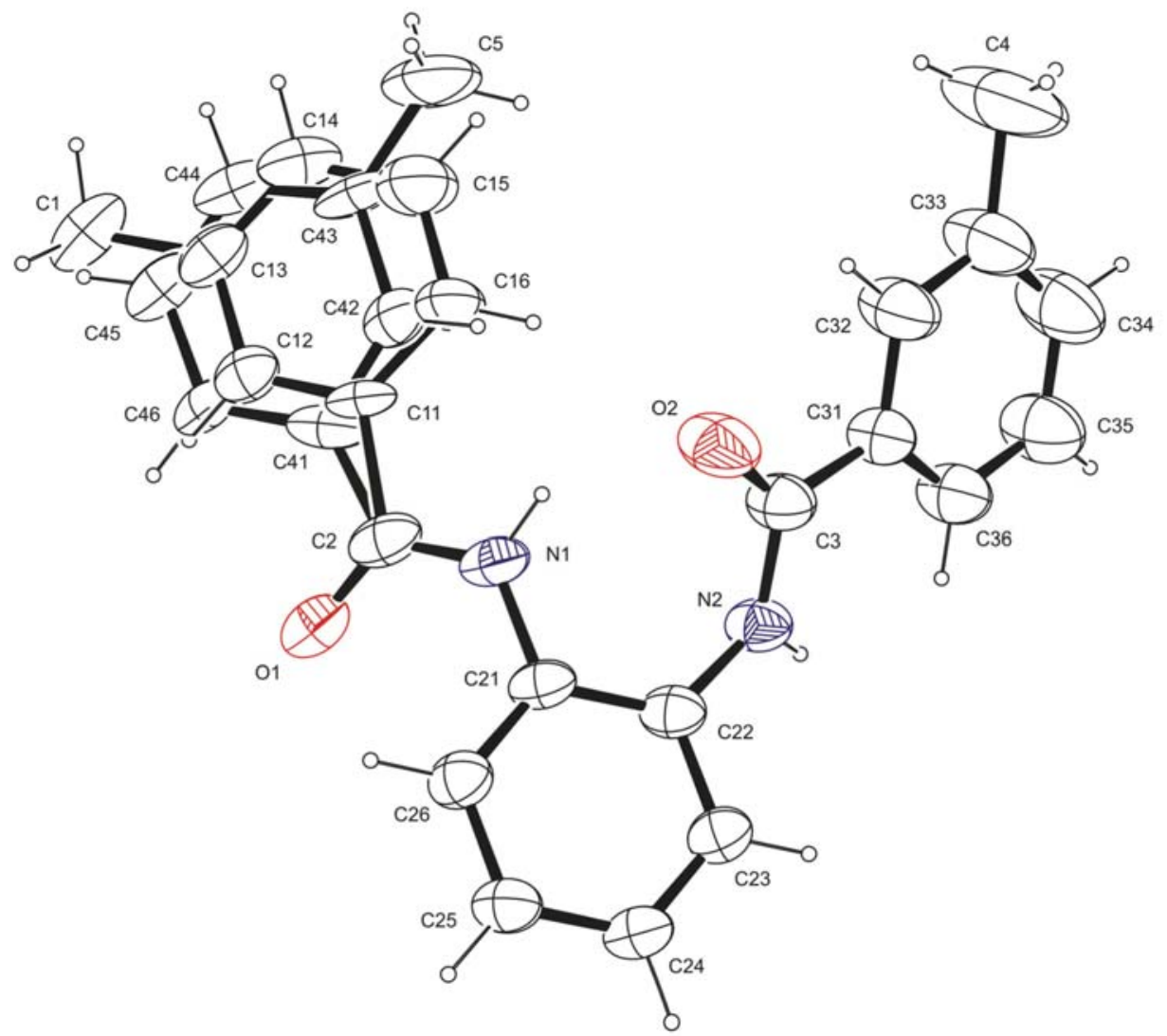

Figure 2. An ORTEP view of compound I showing 50\% probability displacement ellipsoids and the atom labelling. 
Table 2 Selected bond lengths $(\AA)$, bond angles $\left(^{\circ}\right)$ and torsion angles $\left({ }^{\circ}\right)$ of compounds I and II

\begin{tabular}{|c|c|c|c|}
\hline \multicolumn{4}{|c|}{ Bond lengths $(\AA)$} \\
\hline I & & & \\
\hline $\mathrm{O}(1)-\mathrm{C}(2)$ & $1.238(1)$ & $\mathrm{N}(1)-\mathrm{C}(21)$ & $1.387(2)$ \\
\hline $\mathrm{O}(2)-\mathrm{C}(3)$ & $1.239(2)$ & $\mathrm{N}(2)-\mathrm{C}(2)$ & $1.362(1)$ \\
\hline $\mathrm{N}(1)-\mathrm{C}(2)$ & $1.339(1)$ & $\mathrm{N}(1)-\mathrm{C}(2)$ & $1.322(2)$ \\
\hline $\mathrm{N}(1)-\mathrm{C}(21)$ & $1.416(2)$ & $\mathrm{N}(2)-\mathrm{C}(22)$ & $1.377(2)$ \\
\hline $\mathrm{N}(2)-\mathrm{C}(3)$ & $1.356(2)$ & $\mathrm{C}(1)-\mathrm{C}(13)$ & $1.507(2)$ \\
\hline $\mathrm{C}(2)-\mathrm{C}(11)$ & $1.553(1)$ & $\mathrm{C}(2)-\mathrm{C}(11)$ & $1.464(2)$ \\
\hline $\mathrm{N}(2)-\mathrm{C}(22)$ & $1.422(2)$ & $\mathrm{C}(11)-\mathrm{C}(12)$ & $1.393(2)$ \\
\hline $\mathrm{C}(2)-\mathrm{C}(41)$ & $1.400(2)$ & $C(12)-C(13)$ & $1.389(2)$ \\
\hline \multicolumn{4}{|c|}{ Bond angles $\left({ }^{\circ}\right)$} \\
\hline $\mathbf{I}$ & & & \\
\hline $\mathrm{O}(1)-\mathrm{C}(2)-\mathrm{N}(1)$ & $122.6(2)$ & $\mathrm{C}(2)-\mathrm{N}(2)-\mathrm{C}(22)$ & $106.9(1)$ \\
\hline $\mathrm{N}(1)-\mathrm{C}(21)-\mathrm{C}(26)$ & $120.9(2)$ & $\mathrm{C}(2)-\mathrm{N}(1)-\mathrm{C}(21)$ & 104.9(1) \\
\hline $\mathrm{O}(1)-\mathrm{C}(2)-\mathrm{C}(11)$ & $124.5(1)$ & $\mathrm{N}(1)-\mathrm{C}(2)-\mathrm{N}(2)$ & $112.9(1)$ \\
\hline $\mathrm{O}(1)-\mathrm{C}(2)-\mathrm{C}(41)$ & $107.8(1)$ & $\mathrm{N}(2)-\mathrm{C}(2)-\mathrm{C}(11)$ & $122.3(1)$ \\
\hline $\mathrm{O}(2)-\mathrm{C}(3)-\mathrm{N}(2)$ & $121.8(2)$ & $\mathrm{N}(1)-\mathrm{C}(2)-\mathrm{C}(11)$ & $124.7(1)$ \\
\hline $\mathrm{N}(1)-\mathrm{C}(2)-\mathrm{C}(11)$ & $112.9(1)$ & $\mathrm{N}(1)-\mathrm{C}(21)-\mathrm{C}(22)$ & $109.7(1)$ \\
\hline $\mathrm{O}(2)-\mathrm{C}(3)-\mathrm{C}(31)$ & $120.9(2)$ & $\mathrm{N}(2)-\mathrm{C}(22)-\mathrm{C}(21)$ & $105.5(1)$ \\
\hline $\mathrm{C}(2)-\mathrm{N}(1)-\mathrm{C}(21)$ & $125.2(2)$ & $\mathrm{N}(1)-\mathrm{C}(21)-\mathrm{C}(26)$ & 130.1(1) \\
\hline $\mathrm{C}(3)-\mathrm{N}(2)-\mathrm{C}(22)$ & $126.8(1)$ & $\mathrm{C}(2)-\mathrm{C}(11)-\mathrm{C}(16)$ & $121.3(1)$ \\
\hline \multicolumn{4}{|c|}{ Torsion angles $\left(^{\circ}\right)$} \\
\hline I & & & \\
\hline$\overline{\mathrm{C} 21-\mathrm{N} 1-\mathrm{C} 2-\mathrm{C} 11}$ & $180.0(1)$ & $\mathrm{C} 21-\mathrm{N} 1-\mathrm{C} 2-\mathrm{N} 2$ & $-0.3(1)$ \\
\hline $\mathrm{C} 22-\mathrm{N} 2-\mathrm{O} 3-\mathrm{O} 2$ & $5.3(1)$ & $\mathrm{C} 21-\mathrm{N} 1-\mathrm{C} 2-\mathrm{C} 11$ & $-178.6(1)$ \\
\hline C2-N1-C21-C22 & $138.9(2)$ & $\mathrm{N} 1-\mathrm{C} 2-\mathrm{C} 11-\mathrm{C} 12$ & $-27.3(2)$ \\
\hline $\mathrm{O} 1-\mathrm{C} 2-\mathrm{C} 11-\mathrm{C} 16$ & $-166.8(1)$ & $\mathrm{N} 1-\mathrm{C} 2-\mathrm{C} 11-\mathrm{C} 16$ & $151.9(1)$ \\
\hline N1-C2-C11-C16 & $11.4(1)$ & $\mathrm{N} 2-\mathrm{C} 2-\mathrm{C} 11-\mathrm{C} 12$ & $154.6(1)$ \\
\hline O2-C3-C31-C3 & $175.8(1)$ & $\mathrm{N} 1-\mathrm{C} 21-\mathrm{C} 22-\mathrm{N} 2$ & $-0.3(1)$ \\
\hline C2-C11-C16-C15 & 179.4(1) & C2-N1-C21-C26 & $178.6(1)$ \\
\hline C11-C12-C13-C14 & $0.3(1)$ & N2-C2-C11-C16 & $-26.2(2)$ \\
\hline N1-C21-C22-N2 & $-3.9(1)$ & $\mathrm{N} 1-\mathrm{C} 21-\mathrm{C} 22-\mathrm{C} 23$ & $177.9(1)$ \\
\hline N1-C21-C26-C25 & $177.7(2)$ & $\mathrm{N} 1-\mathrm{C} 21-\mathrm{C} 26-\mathrm{C} 25$ & $-177.3(1)$ \\
\hline
\end{tabular}

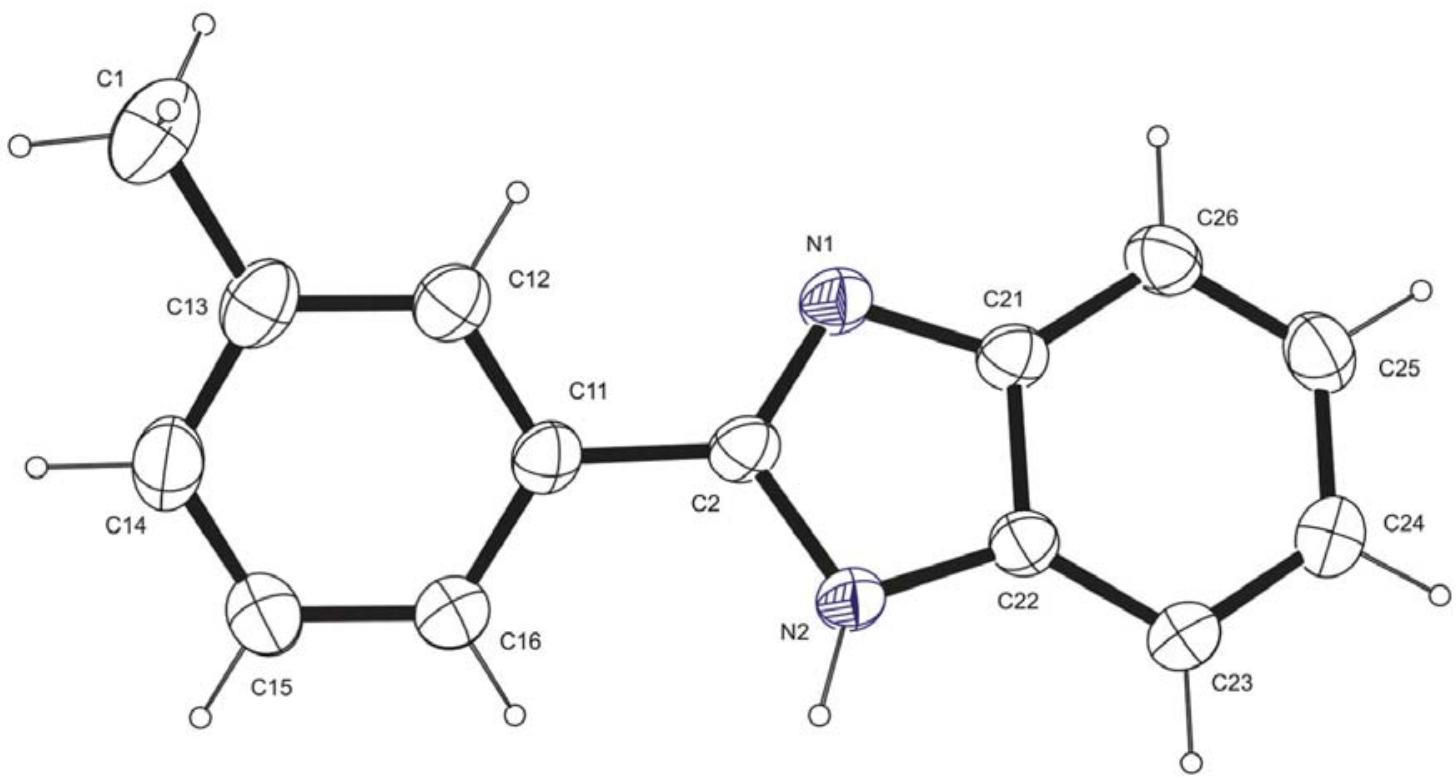

Figure 3. An ORTEP view of compound II showing 50\% probability displacement ellipsoids and the atom labelling. 
THF (1:2) and obtained as a white solid. The computed and crystallographic data and selected bond lengths and bond angles for all the crystal structures are provided in Tables 1 and 2. Selected torsion angles are also provided in Table 3. The ORTEP diagrams for compounds I and II are presented in Figures 2 and 3. Compound I crystallized in the trigonal space group $R-3$, while compound II crystallized in the monoclinic space group $P 2 / c$.

The bond distances of $\mathrm{N}(1)-\mathrm{C}(2)$, and $\mathrm{N}(2)-\mathrm{C}(3)$, which were 1.339(2), and 1.356(2) A, respectively, were consistent with the $\mathrm{C}-\mathrm{N}$ bond of the amide of compound $\mathbf{I}$ whilst $\mathrm{N}(2)-\mathrm{C}(22)$ and $\mathrm{N}(1)-\mathrm{C}(21)$ were $1.422(2)$ and 1.416(2) $\AA$, showing the $\mathrm{C}-\mathrm{N}$ with the carbon being part of the aromatic ring system. Compound $\mathbf{I}$ exhibits a disorder in one of its toluene rings with a disorder ratio of 0.675:0.325.

The bond distances of $\mathrm{O}(1)-\mathrm{C}(2)$ and $\mathrm{O}(2)-\mathrm{C}(3)$ which were 1.238(3) and 1.239(2) $\AA$, respectively, in compound I show usual $\mathrm{C}=\mathrm{O}$ double bond character. The bond lengths are comparable with the average bond length of $\mathrm{C}=\mathrm{O}$ bonds on the $\mathrm{CCDC}$ database which is $1.228 \AA \mathrm{A}^{22}$ The torsion angles $\mathrm{C} 22-\mathrm{N} 2-\mathrm{C} 3-\mathrm{O} 2$ and $\mathrm{C} 21-\mathrm{N} 1-\mathrm{C} 2-\mathrm{O} 2$ in compound $\mathbf{I}$ were $5.3(3)^{\circ}$ and $180.00(3)^{\circ}$, respectively. The torsion angles are consistent with the $\mathrm{O}-\mathrm{C}-\mathrm{N}-\mathrm{C}$ torsion angles of amide-containing compounds on the CCDC database. ${ }^{23}$ The $\mathrm{O}(1)-\mathrm{C}(2)-\mathrm{N}(1), \mathrm{O}(1)-\mathrm{C}(2)-\mathrm{C}(11)$ and $\mathrm{O}(1)-\mathrm{C}(2)-\mathrm{C}(41)$ bond angles which were 122.62 (2), $124.50(4)$ and $107.80(7)^{\circ}$, respectively, were the angles around the $\mathrm{sp}^{2}$ carbon atoms of the carbonyl in compound I. The disorder in the molecule was clearly shown by the two different angles around $\mathrm{C}(2)$ with one angle being narrower than the other. These are comparable to the average $\mathrm{O}-\mathrm{C}-\mathrm{N}$ bond angle on the $\mathrm{CCDC}$ database which is $122.30^{\circ} .{ }^{23}$ In compound II, the two aromatic rings are planar as seen from the torsion angles; N1-C21-C26-C25 $=-177.3(12), \mathrm{N} 1-\mathrm{C} 21-\mathrm{C} 22-\mathrm{C} 23=177.88(11)$ and $\mathrm{N} 1-\mathrm{C} 21-\mathrm{C} 22-\mathrm{N} 2=-0.31(13)$. The dihedral angle bet- ween the toluene ring and the benzimidazole ring is approximately $27^{\circ}$.

An intramolecular hydrogen bond exists in compound $\mathbf{I}$ between a nitrogen $\mathrm{N}(2)-\mathrm{H}$ atom and the oxygen (O1) of the adjacent carbonyl on the same molecule. The oxygen (O2) of a carbonyl and nitrogen $\mathrm{N}(1)-\mathrm{H}$ atom of one molecule form hydrogen bonds with the nitrogen $\mathrm{N}(1)-\mathrm{H}$ atom of another molecule and the oxygen (O2) atom of its carbonyl, respectively. This allows two molecules of compound I to form a dimer (Figure S7). The disorder in compound $\mathbf{I}$ is indicated in Figure 2 on one of the toluene rings. The packing of compound $\mathbf{I}$ shows eighteen molecules in the unit cell (Figure S8). The intermolecular hydrogen bond in compound II occurs between a nitrogen $\mathrm{N}(2)-\mathrm{H}$ and the adjacent nitrogen $\mathrm{N}(1)-\mathrm{H}$ atom of an adjacent molecule (Figure S9). The packing of compound II shows four molecules in the unit cell (Figure S10).

\section{2. HOMO-LUMO Analysis}

Table 3 gives the computed HOMO-LUMO energies for $o$-phenylenediamine, $m$-toluolyl chloride, $m$-toluic acid, 3-chlorotoluene, 4-nitrotoluene and compounds I and II. The frontier orbitals of $m$-toluic acid, which was used in the synthesis of compound II, are shown in Figu-

Table 3: Summary of the HOMO-LUMO energies for $o$-phenylenediamine, $m$-toluolyl chloride, $m$-toluic acid, and compounds I and II.

\begin{tabular}{lccc}
\hline & $\begin{array}{c}\text { HOMO } \\
(\mathbf{k J} / \mathbf{m o l})\end{array}$ & $\begin{array}{c}\text { LUMO } \\
(\mathbf{k J} / \mathbf{m o l})\end{array}$ & $\begin{array}{c}\text { HOMO-LUMO } \\
\text { Gap }(\mathbf{k J} / \mathbf{m o l})\end{array}$ \\
\hline -Phenylenediamine & -520.93 & -37.70 & 483.23 \\
$m$-Toluoyl chloride & -692.24 & -197.04 & 495.20 \\
$m$-Toluic acid & -684.65 & -165.64 & 519.01 \\
Compound I & -620.93 & -163.23 & 457.70 \\
Compound II & -573.91 & -144.61 & 429.30 \\
\hline
\end{tabular}
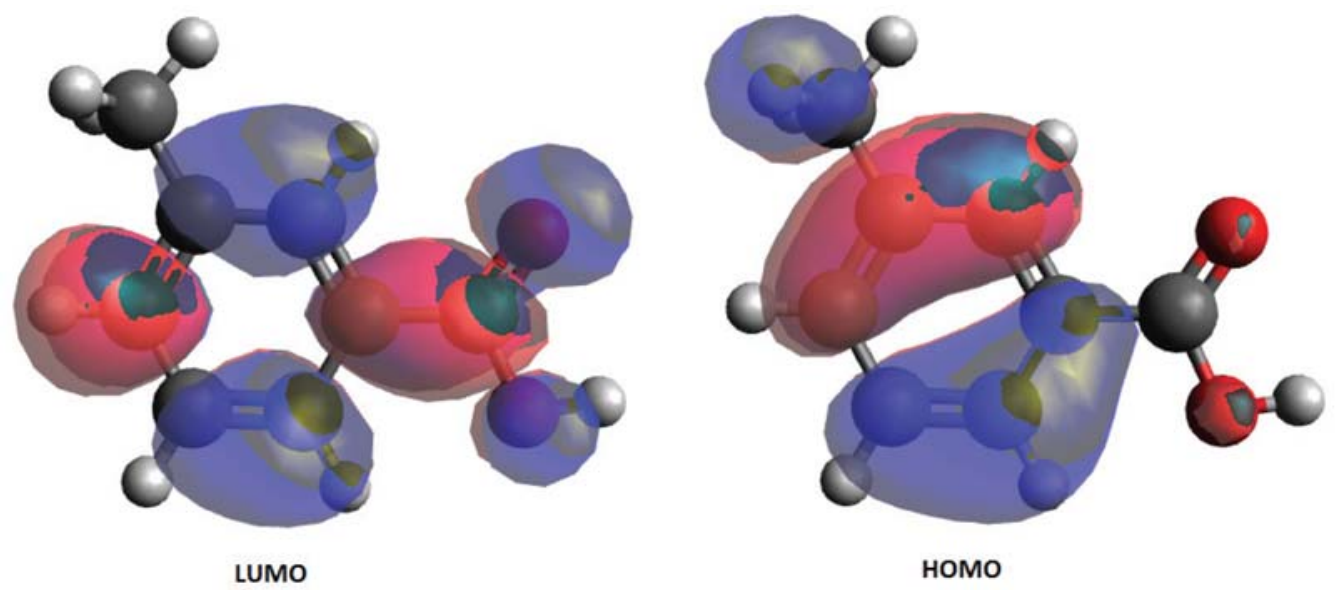

номо

Figure 4. The atomic orbitals composition of the frontier molecular orbital for $m$-toluic acid. 
re 4. The HOMO is delocalised over the entire molecule except the carbonyl group whilst the LUMO is largely delocalised over the entire molecule except the methyl group. This indicates that during charge transfer in a reaction the molecule is stabilised by delocalization of electrons over the entire molecule and also confirming the susceptibility of the carbonyl to attack by the $o$ phenylenediamine.

The frontier orbitals of $m$-toluoyl chloride, which was used for the synthesis of compound $\mathbf{I}$, are shown in Figure 5. The HOMO is delocalised over the entire molecule except the chloride, and the LUMO is also delocalised over the entire molecule except the methyl group. This confirms the susceptibility of the molecule to attack by $o$ phenylenediamine (a nucleophile). During charge transfer in this reaction the molecule is stabilised by delocalization

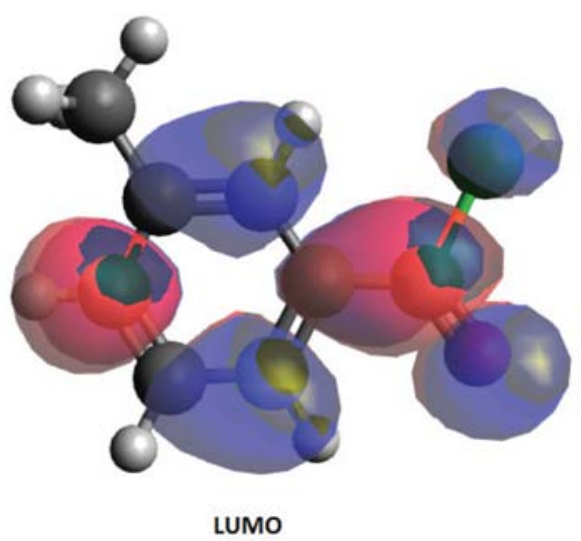

of electrons over the entire molecule. The contribution of the carbonyl carbon atom and the chloride to the LUMO confirm the susceptibility of carbonyl attack by nucleophiles and subsequent loss of chloride.

Figure 6 shows the frontier orbitals of $o$-phenylenediamine which was used in the syntheses of compounds I and II. The HOMO is delocalised over the entire molecule while the LUMO is largely delocalised over the nitrogen atoms and portions of the benzene ring. The high electron density on the nitrogen atom enables it to attack the carbonyl centre in the synthesis of a diamide. In the synthesis of benzimidazoles in an acidic medium there is no loss of a proton but the delocalization of the HOMO on the nitrogen allows the diamine to attack the highly susceptible protonated carbonyl of the carboxylic acid.

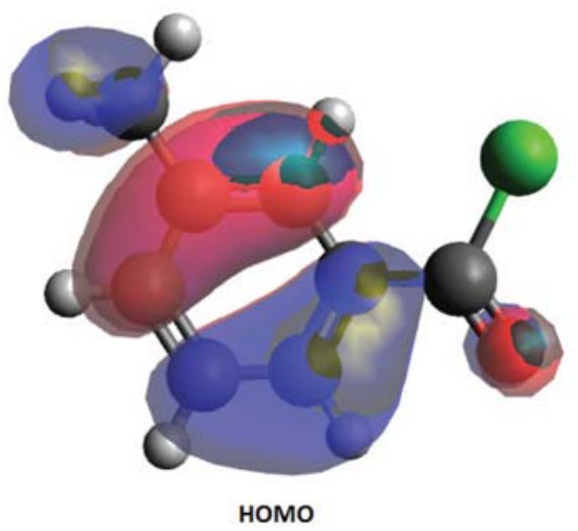

Figure 5. The atomic orbitals compositions of the Frontier molecular orbitals for $m$-toluolyl chloride.
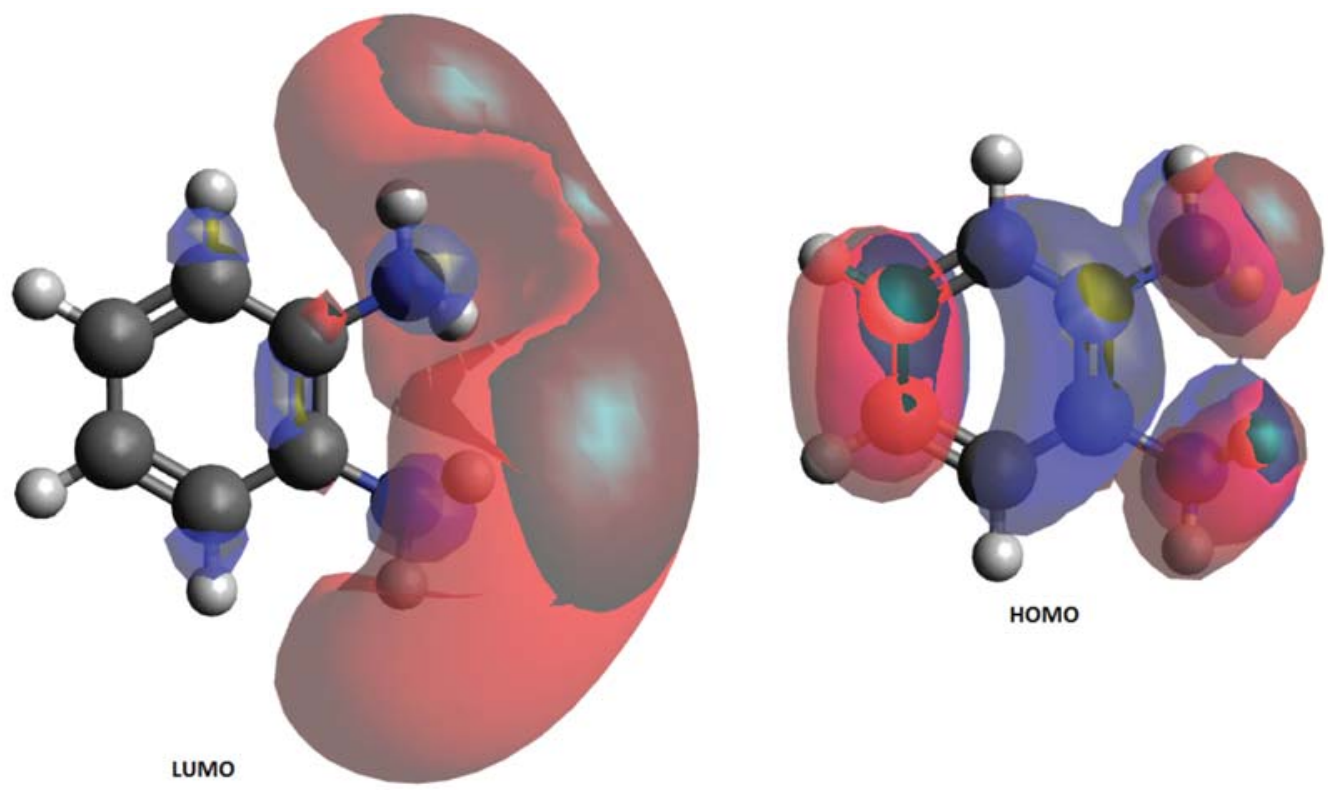

Figure 6. The atomic orbitals compositions of the frontier molecular orbital for $o$-phenylenediamine. 

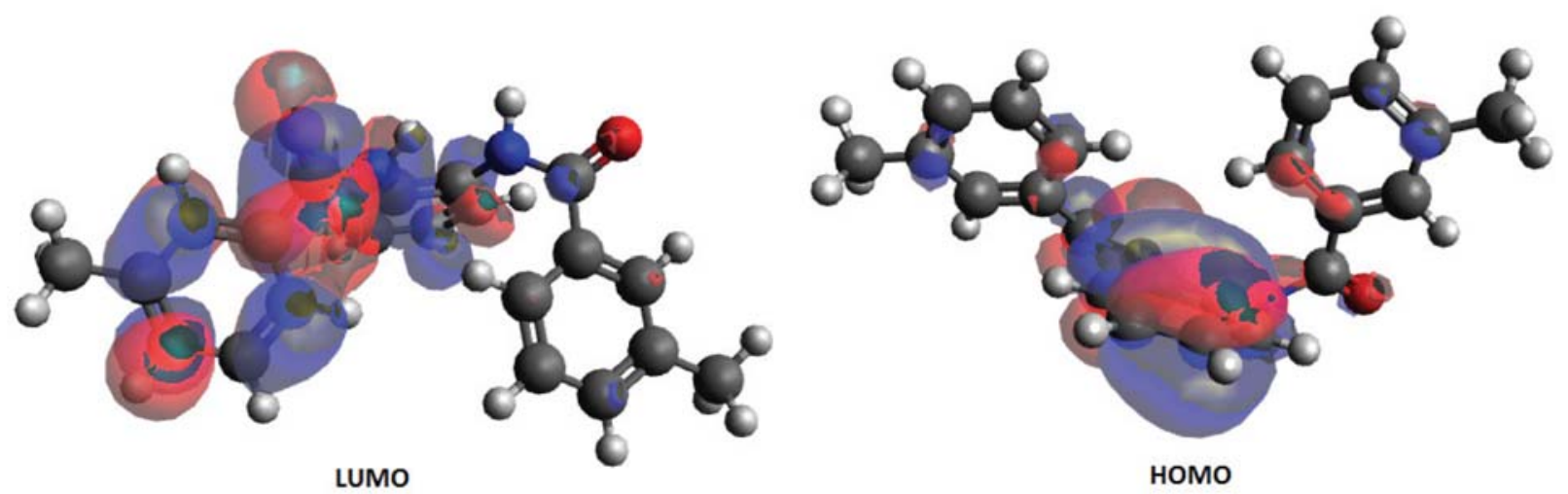

Figure 7. The atomic orbitals compositions of the frontier molecular orbital for compound $\mathbf{I}$.
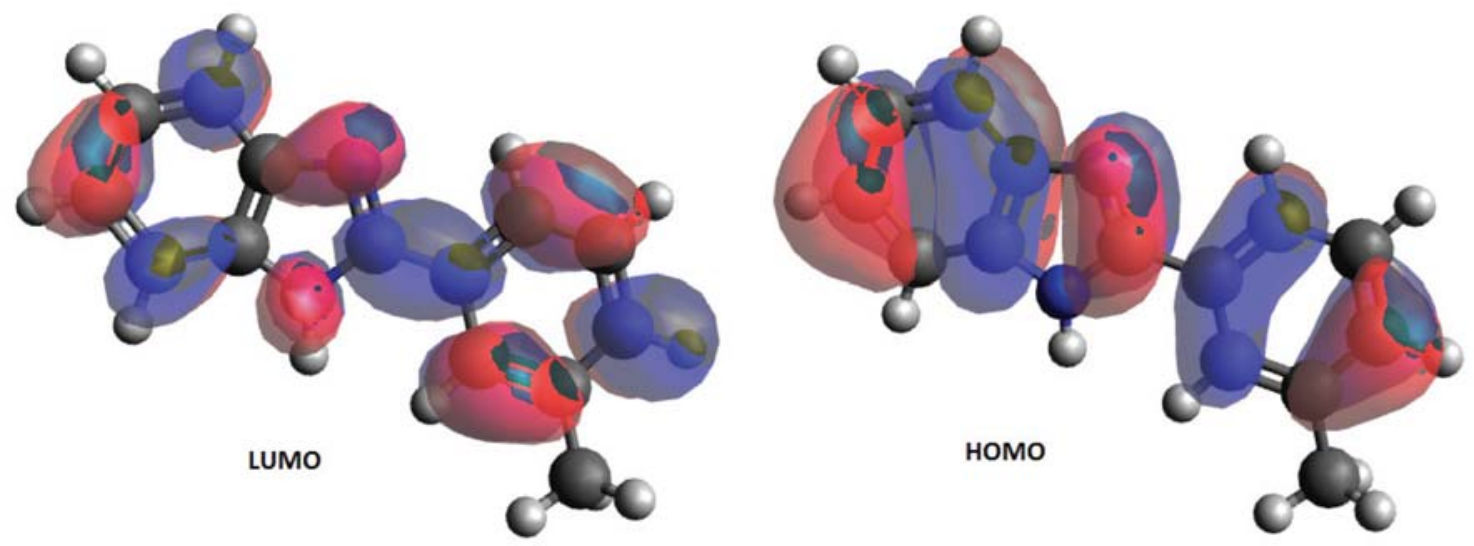

Figure 8. The atomic orbitals compositions of the frontier molecular orbital for compound II.

Figure 7 shows the frontier orbitals of compound $\mathbf{I}$. The HOMO is largely delocalised over the benzene ring contributed by $o$-phenylenediamine, the nitrogen and the carbonyl groups while the LUMO is delocalised over the benzene ring contributed by $o$-phenylenediamine and one of the benzene rings contributed by $m$-toluolyl chloride. The disorder in the molecule observed from its crystal structure is understood since the rings contributed by $m$-toluolyl chloride would have different reactivities.

Figure 8 shows the frontier orbitals of compound II. The HOMO and LUMO are largely delocalised over the entire molecule except the methyl group. This confirms the stability of the molecule to attack by an incoming group, possibly due to charge transfer via delocalization over the entire molecule. This also confirmed the inability to convert the methyl group on compound II to a carboxylic acid by a reaction with potassium permanganate or to an aldehyde by using selenium dioxide.

\section{Conclusions}

3-Methyl- $N$-[2-(3-methylbenzamido)phenylbenzamide (I) has been synthesized by the reaction between $m$-toluolyl chloride and $o$-phenylenediamine. 2-(3Methylphenyl)-1 $H$-benzimidazole (II) has been synthesized from a reaction of $o$-phenylenediamine with $m$-toluic acid in polyphosphoric acid and toluene. In the synthesis of the amide from a diamine, the presence of a good leaving group attached to the carbonyl as in the case of acyl chlorides seems to enable the reaction to proceed with ease. The presence of an excess of a protonating agent and high temperature seem to promote the formation of benzimidazoles. The reactivities of the various functional groups on the compounds based on the contribution to the frontier orbitals have been predicted. The lack of oxidation of the methyl group on the benzimidazole has been discussed.

\section{Supplementary Material}

CCDC numbers 1013218 and 1014054 contain the supplementary crystallographic data (CIF) for this article. These data can be obtained free of charge from or emaildeposit@ccdc.cam.ac.uk. Supplementary data associated with this article can be found in the online version. 


\section{Acknowledgements}

The authors are grateful to the Medical Research Council (MRC) of South Africa for funding and Felix Odame would also like to thank the Faculty of Science (NMMU) for awarding him a bursary for his studies. We would also like to express our gratitude to the Centre for High Performance Computing (CHPC) in Cape Town for the use of their resources.

\section{References}

1. B. N. B. Vaidehi, G. K. Deepika, R. V Satya, R. Bangaramma, H. Kunar, Y. R. Sudha, T. R. Kumar, IJRPC. 2012, 2, (2), 322-326.

2. V. D. Patil, G. Medha, M. Shramesha, J. Aarti, Der Chemica Sinca 2010, 1, (2) 125-129.

3. K. Hirano, A. T. Biju, F. Glorius, J. Org. Chem. 2009, 74, 9570-9572. http://dx.doi.org/10.1021/jo902160y

4. D. Yang, H. Fu, L. Hu, Y. Jiang, Y. Zhao, J. Org. Chem. 2008, 73, (19) 7841-7844.

http://dx.doi.org/10.1021/jo8014984

5. F. M. Rivas, A. J. Giessert, S. T. Diver, J. Org. Chem. 2002, 67, 1708-1711. http://dx.doi.org/10.1021/jo016251n

6. S. O. Vartanyan, A. B. Sargsyam, A. S. Avakyam, E. A. Markaryn, T. O. Asatryan, Russ. J. Org. Chem. 2012, 4,8 (7), 972-976.

7. A. G. N. Christian, V. F. Montalbetti, Tetrahedron 2005, 61, 10827-10852. http://dx.doi.org/10.1016/j.tet.2005.08.031

8. M. Hosseini-Sarvari, H. Shargh, J. Org. Chem. 2006, 71 6652-6654. http://dx.doi.org/10.1021/jo060847z

9. B. C. Ranu, P. Dutta, Synth. Commun. 2003, 33, 297-301. http://dx.doi.org/10.1081/SCC-120015715
10. C. Han, J. P. Lee, E. Lobkovsky, J. A. Porco Jr, J. Am. Chem. Soc. 2005, 127, 10039-10044. http://dx.doi.org/10.1021/ja0527976

11. Y. Suto, N. Yamagiwa, Y. Torisawa, Tetrahedron 2008, 49, (40) 5732-5735. http://dx.doi.org/10.1016/j.tetlet.2008.07.075

12. Y. Zhang, C. Chan, S. C. Ghosh, Y. Li, S. H. Hong, Organometallics 2010, 29, 1374- 1378. http://dx.doi.org/10.1021/om901020h

13. E. Rafiee, N. Rahpeima, S. Eavani, Acta Chim. Slov. 2014, 61, 177-184.

14. C. H. Choi, M. Kertez, J. Phys. Chem. A 1997, 101, 38233831. http://dx.doi.org/10.1021/jp970620v

15. M. Kurt, P. Chinna Babu, N. Sundaraganesan, M. Cinar, M. Karabacak, Spectrochim. Acta A 2011, 79, 1162-1170. http://dx.doi.org/10.1016/j.saa.2011.04.037

16. D. F. V. Lewis, C. D. V. Ioannides, Xenobiotica 1994, 24, 401-408. http://dx.doi.org/10.3109/00498259409043243

17. L. Padmaja, R. C. Kunar, D. Sajan, I. H. Joe, V. S. Jayakunmar, G. R. Pettit, O. F. Nielsen, J. Raman Spectrosc. 2009, 40, 419-428. http://dx.doi.org/10.1002/jrs.2145

18. A. Poiyamozhi, N. Sundaraganesan, M. Karabacak, O. Tanriverdi, M. Kurt. J. Mol. Struc. 2012, 1024, 1-12. http://dx.doi.org/10.1016/j.molstruc.2012.05.008

19. P. Udhayakala, A. Jayanthi, T. V. Rajendiran, S. Gunasekaran, Arch. Appl. Sci. Res. 2011, 3 (4) 424-439.

20. APEX2, SADABS and SAINT. Bruker AXS Inc: Madison, WI, USA, 2010.

21. G. M. Sheldrick, Acta. Cryst. A 2008, 64, 112-122. http://dx.doi.org/10.1107/S0108767307043930

22. C. B. Hübschle, G. M. Sheldrick, B. Dittrich, J. Appl. Cryst. 2011, 44, 1281-1284. http://dx.doi.org/10.1107/S0021889811043202

23. F. H. Allen, Acta. Cryst B 2002, 580, 380-388. http://dx.doi.org/10.1107/S0108768102003890

\section{Povzetek}

Reakcije kislinskih kloridov $\mathrm{z}$ diamini dajejo diamide. $m$-Metilbenzojsko kislino smo pretvorili $\mathrm{v} m$-toluil klorid ter ga nadalje reagirali s 4-metil-o-fenilendiaminom v piridinu in tako pripravili 3-metil- $N$-[2-(3-metilbenzamido)fenilbenzamid (I). 2-(3-Metilfenil)-1 $H$-benzimidazol (II) smo pripravili z reakcijo med $o$-fenilendiaminom in $m$-metilbenzojsko kislino v polifosforni kislini in toluenu. Obe spojini smo karakterizirali z IR, NMR, elementno mikroanalizo ter GC-MS. V razpravo sta vključeni tudi kristalni strukturi pripravljenih spojin. S pomočjo DFT izračunov energij mejnih molekulskih orbital za prekurzorske spojine smo ugotovili, katere skupine prispevajo h HOMO in LUMO in nadalje preučili njihov vpliv na reaktivnost pri tvorbi diamidov in benzimidazolov. Izkazalo se je, da je nastanek amidov iz diaminov prednosten v prisotnosti dobrih izstopajočih skupin vezanih ob karbonilni skupini; takšen primer so kislinski kloridi. Po drugi strani pa je nastanek benzimidazolov prednosten v primeru, ko uporabimo presežek protonacijskega reagenta in ko reakcije izvajamo pri visokih temperaturah. 